\title{
Pengaruh Academic Self Efficacy terhadap Penyesuaian Akademik Mahasiswa pada Pembelajaran Jarak Jauh
}

\author{
Gita Safira* \\ Prodi Ilmu Psikologi, Fakultas Psikologi, Universitas Islam Bandung, \\ Indonesia. \\ *gitasafira231@gmail.com
}

\begin{abstract}
One of the impacts of the COVID-19 pandemic is the transfer of face-to-face learning methods to online learning methods. These method changes, causing students need to adapt to distance learning methods. Success in academic adjustment, one of which depends on self-efficacy. This study aims to see how much influence academic self-efficacy has on academic adjustment to students in the city of Bandung who are implementing online learning. The sample in this study were 400 students in the city of Bandung. Student academic self-efficacy was measured using the Academic self-efficacy Scale belonging to Zajacova, Lynch, \& Espenshade (2005) and has been adapted by Rauf (2015) and student academic adjustment was measured using Baker\&Siryk's Student Adaptation to College Questionnaire (SACQ) ( 1984) which has been adapted by Rahayu and Arianti (2020). The data in this study were analyzed using a simple linear regression test and showed the results that academic self-efficacy had an effect on the academic adjustment of students in Bandung $(\mathrm{R} 2=0.353 ; \mathrm{P}=0.00)$, This means the influence of academic self-efficacy on academic adjustment was $35.3 \%$ while the remaining $64.7 \%$ is influenced by other factors not examined in this study. The results of this study also show that one dimension of the four dimensions of academic self-efficacy doesn't have any affect in increasing academic adjustment, the dimension is managing work, family, and school.
\end{abstract}

Keywords: Academic self efficacy, Student, Online learning, Academic Adjustment.

Abstrak. Salah satu dampak pandemic.COVID-19 adalah dialihkannya metode pembelajaran tatap muka menjadi metode pembelajaran jarak jauh. Perubahan.metode tersebut, menyebabkan mahasiswa perlu menyesuaikan dengan metode pembelajaran jarak jauh. Keberhasilan dalam penyesuaian akademik, salah satunya dipengaruhi dengan self efficacy. Penelitian.ini.bertujuan untuk melihat seberapa besar pengaruh academic self efficacy terhadap penyesuaian akademik pada mahasiswa di kota Bandung yang sedang melaksanakan pembelajaran jarak jauh. Sampel pada penelitian ini sebanyak 400 mahasiswa aktif di kota Bandung. Academic self efficacy mahasiswa diukur dengan menggunakan alat ukur Academic self efficacy Scale milik Zajacova, Lynch, \& Espenshade (2005) dan telah diadaptasi oleh Rauf (2015) dan penyesuaian akademik mahasiswa diukur menggunakan alat ukur Student Adaptation to College Questionnaire (SACQ) milik Baker\&Siryk (1984) yang telah diadaptasi oleh Rahayu dan Arianti (2020). Data pada penelitian ini dianalisis menggunakan uji regresi linier sederhana dan menunjukkan hasil bahwa academic self efficacy berpengaruh terhadap penyesuaian akademik mahasiswa di kota bandung $(R 2=0,353$; $\mathrm{P}=0,00$ ), artinya pengaruh academic self efficacy terhadap penyesuaian akademik sebesar $35,3 \%$ sedangkan $64,7 \%$ sisanya dipengaruhi oleh faktor lain yang tidak diteliti dalam penelitian ini. Hasil penelitian ini juga menunjukkan bahwa dari empat dimensi academic self efficacy ada satu dimensi yang tidak berperan dalam meningkatkan penyesuaian akademik yaitu dimensi managing work, family, and school.

Kata Kunci: Academic self efficacy, Mahasiswa, Pembelajaran Jarak Jauh (PJJ), Penyesuaian Akademik. 


\section{A. Pendahuluan}

Di akhir tahun 2019 ditutup dengan menyebarnya Corona Virus Disease (Covid-19). Jumlah penderita virus covid di kota-kota besar termasuk kota Bandung terus melonjak setiap hari. Oleh karena itu, pemerintah Indonesia melarang perguruan tinggi memberikan kuliah tatap muka dan menginstruksikan perguruan tinggi untuk melaksanakan kuliah dengan metode jarak jauh (Sadikin \& Hamidah, 2020).

Pelaksanaan pembelajaran jarak jauh ini dilaksanakan dengan tidak adanya pertemuan fisik antara mahasiswa dan dosen, yang dapat dilakukan menggunakan teknologi seperti ponsel pintar, komputer atau laptop yang terhubung dengan internet (Griffiths, 2016 dan Hoi \& Lu, dalam Didin, et al, 2020). Hal tersebut mengakibatkan beberapa dosen mengubah aktivitas belajar mengajar dengan cara pemberian tugas kepada mahasiswanya. Dengan diberikannya tugas ini menimbulkan berbagai keluhan dari mahasiswa. Salah satunya mahasiswa merasakan sulit beradaptasi dengan metode yang baru karena jumlah tugas yang berlipat ganda, kuota jaringan cepat habis, dan koneksi tidak stabil (Mudakompas.id dan Bulplus, 2020).

Susanti dan Sholeh (2008), menganggap pembelajaran jarak jauh dapat membantu proses pembelajaran. Sehingga, jika individu yang dapat memanfaatkan situasi ini, akan memiliki keterampilan dalam manajemen waktu, dan penggunaan teknologi yang relevan, yang akan berdampak positif pada keberhasilan akademis (Taipjutorus, Hansen, \& Brown, 2012). Begitupun Singh, et al (2005) mengemukakan bahwa pembelajaran jarak jauh atau pembelajaran online dapat membentuk jiwa kemandirian dalam belajar, dan dapat mendorong mahasiswa agar lebih asertif, seperti mahasiswa yang biasanya tidak aktif berbicara ketika melaksanakan pembelajaran dengan metode jarak jauh ini diharapkan dapat lebih leluasa dalam menyampaikan pendapat atau pertanyaannya baik secara lisan maupun tertulis.

Namun penelitian Tuncay, et al (2011) didapatkan hasil bahwa pembelajaran yang sepenuhnya dilakukan dengan metode jarak jauh atau daring, dianggap kurang dapat mengakomodasi seluruh kebutuhan pembelajaran. Begitupun pada survei Ditjen Dikti Kemendikbud (2020) mengenai evaluasi metode pembelajaran jarak jauh dengan jumlah responden 230.000 mahasiswa di 32 provinsi, menyatakan bahwa 90\% mahasiswa lebih menyukai kuliah langsung dibandingkan kuliah dengan metode jarak jauh karena mahasiswa terbebani dengan tugas yang banyak (cnnindonesia.com).

Menurut Charismiadji (dalam Hasanah, et al 2020) pembelajaran jarak jauh dilakukan sebagai antisipasi virus covid-19. Namun, hal tersebut dinilai kurang optimal dan menunjukkan bahwa dosen dan mahasiswa masih belum siap untuk beradaptasi dengan lingkungan digital (Hasanah, et al. 2020). Begitupun menurut Ririen dan Hartika (2021) bahwa dengan ditambahnya masa pembelajaran jarak jauh di Perguruan Tinggi membuat mahasiswa resah, karena adanya masalah kesulitan dalam menyesuaikan dengan tuntutan akademik yang baru, seperti banyaknya tugas yang yang harus diselesaikan dalam batas waktu, interaksi yang terbatas antara mahasiswa, dosen, dan teman sebaya, masalah tugas, jaringan, dan hambatan teknis lainnya.

Sehingga pembelajaran jarak jauh membutuhkan penyesuaian, agar dapat berlangsung dengan baik (Argaheni, 2020). Baker \& Siryk (1984) mengungkapkan bahwa penyesuaian diri adalah salah satu peran penting dalam membantu mahawiswa di kampus. Proses penyesuaian tersebut merupakan cara seseorang dalam menghadapi stress, konflik, ketegangan serta untuk memenuhi kebutuhannya (Mutambara \& Bhebe, 2012).

Mahasiswa dituntut menyesuaikan dirinya dengan lingkungan atau situasi yang baru mereka hadapi. Terdapat tiga domain yang dibutuhkan, yaitu penyesuaian akademik, sosial, dan emosi (Friedlander, Reid, Shupak, \& Cribbie, 2007). Anderson et al. (2016) mendefinisikan penyesuaian akademik pada mahasiswa sebagai kemampuan individu untuk mengelola tugas-tugas sosial, psikologis, dan keilmuan. Arkoff, 1968 (dalam Sharma, 2012) pun mengemukakan bahwa penyesuaian terhadap akademik dapat mencerminkan bagaimana seseorang berhasil dalam menjalani tuntutan dan mencapai prestasi di perguruan tinggi.

Berdasarkan penelitian Saniskoro, et al (2020) mahasiswa yang memiliki kemampuan penyesuaian akademik yang tinggi cenderung memiliki stres yang rendah, begitupun 
sebaliknya. Sehingga menurut Sa'idah (2017) agar memiliki kemampuan penyesuaian yang baik, seseorang membutuhkan keyakinan terhadap kemampuan dirinya dalam melakukan aktivitas dengan baik. Chemers, Hu, dan Gracia (2001) pun menyatakan bahwa keyakinan akan kemampuan diri (self efficacy) dan optimisme memainkan peran utama dalam suksesnya individu.

Menurut Bandura (dalam Sa'idah 2017) self efficacy merupakan keyakinan seseorang dapat melakukan suatu aktivitas dengan berhasil. Menurut Sa'idah (2017) self efficacy dapat mengakibatkan seseorang merasa, berfikir dan bertindak, berdasarkan keputusan yang dipilih (Sa'idah, 2017).

Dengan adanya pandemi ini, menyebabkan mahasiswa harus menyesuaikan kembali dengan metode pembelajaran jarak jauh (Indrawati, 2020). Sehingga, keberhasilan ketika menyesuaikan, bergantung pada keyakinan seseorang (self-efficacy) untuk memenuhi tuntutan baru tersebut (Bandura, 1997; Smith \& Betz, 2002).

Alivernini dan Lucidi (2011) menyatakan bahwa self-efficacy adalah prediktor yang baik untuk keberhasilan akademis dan juga membantu siswa dalam beradaptasi dengan baik pada lingkungan belajar yang baru. Self-efficacy dinyatakan sebagai salah satu variabel psikologis terpenting yang dapat mengubah persepsi siswa tentang lingkungan belajar mereka (Pajares, 1996).

Multon, Brown, \& Lent (dalam Zajacova, et al 2005) pun menemukan bahwa selfefficacy yang spesifik di bidang akademik akan lebih akurat dalam memprediksi prestasi akademik daripada self-efficacy secara ganeral. Hal tersebut mendasari penulis dalam melaksanakan penelitian mengenai self-efficacy dan penyesuaian akademik menggunakan variabel yang lebih spesifik, yaitu academic self-efficacy.

Berdasarkan latar belakang yang telah diuraikan, maka perumusan masalah dalam penelitian ini dalah "Apakah terdapat pengaruh academic self efficacy terhadap penyesuaian akademik mahasiswa di Kota Bandung pada pembelajaran jarak jauh?". Selanjutnya, tujuan dalam penelitian ini diuraikan dalam pokok-pokok sbb.

1. Untuk mengetahui academic self efficacy dan penyesuaian akademik mahasiswa di kota Bandung selama pembelajaran jarak jauh.

2. Mengetahui berdasarkan data empiric mengenai pengaruh academic self efficacy terhadap penyesuaian akademik mahasiswa pada pembelajaran jarak jauh.

3. Dan melihat dimensi academic self efficacy mana yang memiliki pengaruh terbesar dalam meingkatkan kemampuan penyesuaian akademik pada mahasiswa di Bandung dalam Pembelajaran Jarak Jauh.

\section{B. Metodologi Penelitian}

Variabel dari penelitian ini adalah academic self efficacy dan penyesuaian akademik. Bandura (1997) menyatakan bahwa academic self efficacy adalah penilaian kemampuan individu untuk mengatur dan melaksanakan pembelajaran agar mencapai hasil yang memuaskan. Lalu Zajacova (2005) juga mendefinisikan academic self efficacy adalah keyakinan mahasiswa terhadap kemampuannya untuk mencapai tujuan pendidikannya, seperti mempersiapkan ujian dan menulis esai agar lulus.

Zajacova et al. (2005) menyatakan terdapat empat dimensi academic self-efficacy, yaitu: 1) Interaction at School, Ketika mahasiswa memiliki keyakinan pada kemampuan di dalam diri dapat berinteraksi dengan semua pihak di perguruan tinggi, termasuk dosen, mengikuti diskusi kelas, bertemu teman di lingkungan kampus, mengajukan pertanyaan di kelas, dan mencari bantuan dan informasi di kampus; 2) Academic performace out of class, Yakin terhadap kemampuannya dan menggunakan kemampuannya di luar kelas untuk memaksimalkan potensi, termasuk menulis esai, mempersiapkan ujian, mengerjakan pekerjaan rumah tepat waktu, mempelajari dan memahami buku teks; 3) Academic performance in class, Yakin terhadap kemampuan diri dapat tampil di kelas atau perkuliahan, seperti mendapat nilai yag baik di kelas yang paling sulit, dan mendapat nilai yang diharapkan; dan 4) Managing work, family, and school, Keyakinan akan kemampuan untuk mengelola pekerjaan, keluarga, dan sekolah secara efektif. 
Javed (2016), Baker dan Siryk (1984) berpendapat bahwa penyesuaian akademik menunjukkan tingkat di mana mahasiswa telah beradaptasi dengan tuntutan akademik di perguruan tinggi, seperti yang ditunjukkan melalui keterlibatan individu terhadap materi perkuliahan; sikap individu terhadap program studi; dan seberapa memadai upaya individu dalam mencapai hasil akademik (dalam Javed, 2020).

Berikut merupakan aspek-aspek penyesuaian akademik yang diturunkan dari teori Baker\&Siryk, yaitu: 1) Motivasi, Beyers dan Goossens (2002) menyatakan bahwa motivasi yang tinggi dapat terjadi karena mahasiswa dapat menyesuaikan dirinya terhadap lingkungan akademiknya. Sehingga, menunjukkan bahawa motivasi adalah suatu hal yang penting dalam berhasilnya mahasiswa dalam menyesuaikan di bidang akademik; 2) Aplikasi, Aplikasi adalah dimana individu dapat melakukan dan mengintegrasikan beberapa keterampilan yang mereka miliki.. Dalam konteks akademik, ketika mahasiswa dapat menyelesaikan tugas dan tuntutan, maka dapat dianggap bahwa mahasiswa tersebut telah mampu menerapkan apa yang dipelajarinya dengan baik (Mudhovozi, 2012); 3) Prestasi, Prestasi akademik yang tinggi dapat menggambarkan proses penyesuaian akademik dapat dilalui dengan baik oleh individu. Individu yang mampu berkonsentrasi dan mengikuti proses belajar dengan baik, menggambarkan ia dapat menyesuaikan diri dengan akademik yang baik (Warsito, 2009); dan 4) Lingkungan Akademik, Lingkungan akademik dapat membantu individu dalam menyesuaikan diri, menerima dan beradaptasi terhadap perubahan yang terjadi. Oleh karena itu, individu perlu secara bijak mengeksplorasi, melalui, menguasai, dan beradaptasi dengan perubahan yang terjadi (Kneipp et al., 2009 dalam Arjanggi \& Kusumaningsih, 2016).

Penelitian ini menggunakan metode kausalitas untuk melihat hubungan sebab-akibat antara dua variabel tersebut.

Alat ukur dalam penelitian ini adalah : Academic self efficacy mahasiswa diukur dengan menggunakan alat ukur Academic self efficacy Scale milik Zajacova, Lynch, \& Espenshade (2005) dan telah diadaptasi oleh Rauf (2015) dan di publikasikan oleh Arlinkasari (2017) dengan nilai validitas 0.944. Skala ini terdapat 22 item. Skor yang diperoleh meggunakan rating scale dari 0 (tidak yakin sama sekali) sampai 10 (sangat yakin). Lalu penyesuaian akademik mahasiswa diukur menggunakan salah satu dimensi dari alat ukur Student Adaptation to College Questionnaire (SACQ) milik Baker\&Siryk (1984) yang telah diadaptasi oleh Rahayu dan Arianti (2020) yang terdiri dari 13 item dan memiliki reliabilitas 0.806. Skor di peroleh menggunakan skala likert dengan rentang skor 1-4 dari tidak sesuai sama sekali hingga sangat sesuai sekali.

Populasi dalam penelitian ini adalah seluruh mahasiswa di perguruan tinggi kota Bandung yang berjumlah 304.281 mahasiswa (Direktori dan PDDikti). Dalam penelitian ini sampel akan ditentukan menggunakan rumus dari Slovin, dengan taraf kesalahan sebesar 5\% maka jumlah sampel yang dihasilkan dari perhitungan rumus Slovin adalah sebanyak 399 mahasiswa di kota Bandung.

Pengambilan sampel dalam penelitian ini dilakukan dengan menggunakan teknik cluster sampling berdasarkan Sub Wilayah Kota (SWK) Bandung yang terdiri dari 8 (delapan) kelompok, yaitu Arcamanik, Cibeunying, Karees, Kordon, Gedebage, Ujungberung, Bojonagara dan Tegalega (Open Data Kota Bandung). Kemudian dari masing-masing SWK Bandung dipilih 1 (satu) perguruan tinggi, sehingga dalam penelitian ini sampel dipilih dari 8 perguruan tinggi.

Penelitian ini akan menganalisis pengaruh academic self efficacy terhadap penyesuaian akademik, hasil penelitian akan dianalisis secara statistik menggunakan teknik regresi linier.

\section{Hasil Penelitian dan Pembahasan}

Berikut adalah hasil penelitian mengenai pengaruh academic self efficacy terhadap penyesuaian akademik yang diuji menggunakan teknik analisis regresi linear. Hasil pengujian dijelaskan pada tabel 1 . 
Tabel 1. Hasil Uji Analisis Regresi Academic self efficacy Terhadap Penyesuaian Akademik

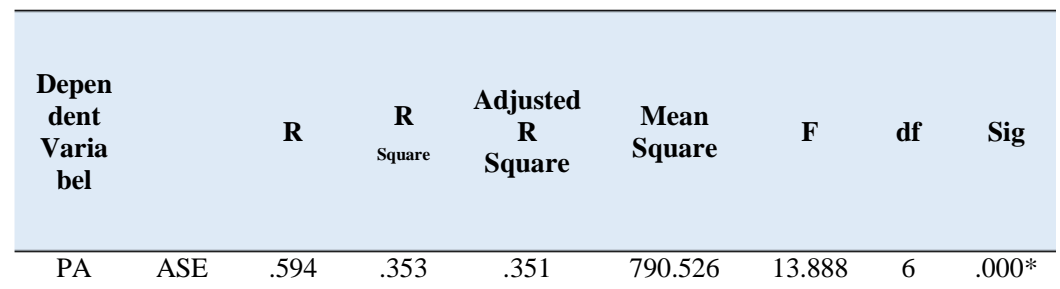

*Signifikansi pada $\mathrm{p}<.005$

Dari tabel di atas, dapat diketahui bahwa Academic Self Efficacy memberikan pengaruh yang signifikan terhadap Penyesuaian Akademik mahasiswa di kota Bandung yang sedang melaksanakan PJJ (.000 <.005). Nilai koefisien determinasi (Adjusted $R$ Square) sebesar .353 yang berarti academic self efficacy memberikan pengaruh sebesar 35,3\% terhadap penyesuaian akademik mahasiswa dan menunjukkan bahwa masih ada $64,7 \%$ faktor lain yang dapat mempengaruhi. Hasil dari penelitian ini didukung dengan penelitian yang dilakukan oleh Sopiyanti (2011) dengan hasil adanya pengaruh antara self efficacy terhadap penyesuaian akademik. Begitupun menurut Bandura (1997) ketika mahasiswa dengan academic self efficacy tinggi akan mempengaruhi prestasi dan penyesuaian akademiknya. Dan Crede \& Niehorster (2011) mengembangkan teori Baker \& Siryk, dimana salah satu faktor yang mempengaruhi penyesuaian akademik adalah self efficacy, yang sejalan dengan penelitian ini yaitu academic self efficacy yang berpengaruh positif terhadap penyesuaian akademik. Dari pernyataan tersebut dapat diketahui bahwa academic self efficacy merupakan kondisi psikologis yang memberikan sebagian kontribusinya terhadap penyesuaian akademik. Bagi mahasiswa dengan academic self efficacy tinggi akan melaksanakan tuntutan akademik dengan baik, seperti berusaha mencapai tujuan akademik, berusaha mendapatkan prestasi yang baik dan menyukai lingkungan akademik yang baru atau juga dapat disebut dapat menyesuaikan akademik dengan baik.

Pada penelitian ini sebagian besar mahasiswa memiliki academic self efficacy yang rendah $(54,5 \%)$. Sehingga perilaku mahasiswa mayoritas kurang memiliki keyakinan dengan kemampuannya di bidang akademik, seperti, misalnya jarang bertanya di kelas, gagal meningkatkan kemampuan literasinya, gagal memperoleh nilai yang diinginkan, mampu mengatur waktu untuk persiapan ujian dan berkumpul dengan keluarga. Kemudian mayoritas mahasiswa di kta Bandung yang sedang melaksanakan pembelajaran jarak jauh mayoritas memiliki kemampuan penyesuaian akademik yang rendah (61,5\%). Sehingga mahasiswa cenderung memiliki keraguan mengenai pentingnya pendidikan dalam perkuliahan, tidak menikmati tuntutan akademik, tidak memiliki motivasi untuk belajar, merasa kesulitan berkonsentrasi, dan tidak merasa puas dengan situasi akademik saat kuliah dengan metode jarak jauh.

Academic self efficacy dan penyesuaian akademik mahasiswa yang rendah ini didukung dengan hasil data deskriptif, yaitu data lama berkuliah mahasiswa yang akan dijelaskan pada tabel 2 . 
Tabel 2. Distribusi Frekuensi Mahasiswa di Kota Bandung yang Sedang Melaksanakan Pembelajarana Jarak Jauh

Berdasarkan Lama Berkuliah

\begin{tabular}{|c|c|c|c|c|c|c|c|c|c|c|c|}
\hline \multicolumn{2}{|c|}{$\begin{array}{l}\text { Lama } \\
\text { Studi }\end{array}$} & \multicolumn{2}{|c|}{ 1th } & \multicolumn{2}{|c|}{ 2th } & \multicolumn{2}{|c|}{ 3th } & \multicolumn{2}{|c|}{ 4th } & \multicolumn{2}{|c|}{$>4$ th } \\
\hline $\mathbf{V}$ & T/R & $\mathbf{T}$ & $\mathbf{R}$ & $\mathbf{T}$ & $\mathbf{R}$ & $\mathbf{T}$ & $\mathbf{R}$ & $\mathbf{T}$ & $\mathbf{R}$ & $\mathbf{T}$ & $\mathbf{R}$ \\
\hline & ASE & $\begin{array}{l}66, \\
3 \\
\%\end{array}$ & $\begin{array}{c}33, \\
7 \\
\%\end{array}$ & $\begin{array}{c}59, \\
7 \\
\%\end{array}$ & $\begin{array}{c}40, \\
3 \\
\%\end{array}$ & $\begin{array}{c}40, \\
2 \\
\%\end{array}$ & $\begin{array}{c}59, \\
8 \\
\%\end{array}$ & $\begin{array}{c}25 \\
4 \\
\%\end{array}$ & $\begin{array}{c}74, \\
6 \\
\%\end{array}$ & $\begin{array}{c}38, \\
5 \\
\%\end{array}$ & $\begin{array}{c}61, \\
5 \\
\%\end{array}$ \\
\hline & $\mathrm{PA}$ & $\begin{array}{c}73, \\
5 \\
\%\end{array}$ & $\begin{array}{c}26, \\
5 \\
\%\end{array}$ & $\begin{array}{c}58, \\
2 \\
\%\end{array}$ & $\begin{array}{c}41, \\
8 \\
\%\end{array}$ & $\begin{array}{c}32, \\
9 \\
\%\end{array}$ & $\begin{array}{c}67, \\
1 \\
\%\end{array}$ & $\begin{array}{c}10, \\
5 \\
\%\end{array}$ & $\begin{array}{c}89, \\
5 \\
\%\end{array}$ & $\begin{array}{c}10, \\
3 \\
\%\end{array}$ & $\begin{array}{c}89, \\
7 \\
\%\end{array}$ \\
\hline
\end{tabular}

Dari tabel di atas, dapat diketahui bahwa dalam penelitian ini di antara 400 mahasiswa yang menerapkan pembelajaran jarak jauh di kota Bandung mayoritas mahasiswa yang telah berkuliah selama 4 tahun sampai $>4$ tahun (lebih dari 4 tahun) memiliki academic self efficacy yang rendah. Hal ini menunjukkan mahasiswa hanya.dapat.menyelesaikan.tugas sederhana dan cenderung menghindari tugas yang dianggap berat atau diluar kemampuan, kemudian mahasiswa tersebutpun mudah mengurangi usaha dan mudah menyerah saat menghadapi rintangan.

Lalu mahasiswa yang telah berkuliah selama 3 tahun sampai $>4$ tahun (lebih dari empat tahun) memiliki kemampuan penyesuaian akademik yang rendah. Menunjukkan bahwa mahasiswa merasa kesulitan dalam mengatasi tantangan di perguruan tinggi, rentan putus sekolah, memiliki masalah dalam hubungan, cemas, depresi, merasa kesepian, dan kesulitan akademik. Hal ini bertolak belakang dengan pernyataan Feldt, et al (2011) yang menyatakan jika perkuliahan di periode 1 tahun pertama dianggap menjadi masa yang menantang, dimana mahasiswa akan bertemu dengan sistem atau metode pembelajaran yang berbeda dengan masa sekolah, sehingga mahasiswa akan kesulitan menyesuaikan dengan situasi yang baru. Namun penelitian ini sejalan dengan pernyataan Ningsih (2020) bahwa mahasiswa yang sudah berkuliah selama 3 tahun lebih sudah terbiasa melakukan perkuliahan tatap muka, sehingga banyak yang merasa kesulitan ketika dialihkannya metode pembelajaran menjadi PJJ.

Kemudian dari beberapa dimensi yang terdiri dalam academic self efficacy, terdapat tiga aspek yang secara signifikan mempengaruhi penyesuaian akademik mahasiswa yaitu interaction at school, academic performance out of class, dan academic performance in class.

Dimensi academic performance out of class, dan academic performance in class di dalam penelitian ini merupakan dimensi yang paling memiliki pengaruh yang besar terhadap penyesuaian akademik. Hal ini berarti mahasiswa yang yakin terhadap kemampuannya dalam mengoptimalkan kinerja selama di luar perkuliahan seperti yakin akan kemampuannya untuk belajar, memahami materi, menyelesaikan tugas tepat waktu, mempersiapkan ujian, dan yakin atas kemampuannya untuk meningkatkan keterampilan membaca dan menulis. Maka semakin tinggi pula kemampuan mahasiswa menikmati tugas akademiknya, puas dengan prestasi akademiknya danpuas terhadap situasi pembelajaran saat ini. Begitu juga dengan mahasiswa yang yakin terhadap kemampuannya dalam mengoptimalkan kinerja selama di dalam kelas seperti keyakinan mahasisiwa akan kemampuannya untuk mengerjakan ujian dengan baik, meraih nilai yang diinginkan, dan mengikuti kelas yang dianggap berat dengan baik.

Kemudian, dimensi interaction at school pun memiliki pengaruh terhadap penyesuaian akademik. Hal ini berarti mahasiswa mahasiswa yang percaya pada kemampuannya untuk berinteraksi dengan pihak-pihak di Perguruan Tinggi seperti mahasiswa yang yakin bahwa dirinya mampu untuk berinteraksi dengan dosen dan staf, yakin akan kemampuannya untuk mencari informasi dan pertolongan di kampus, serta yakin akan kemampuannya untuk memahami peraturan di kampus maka semakin tinggi pula kemampuan mahasiswa menikmati tugas akademiknya, puas dengan prestasi akademiknya danpuas terhadap situasi pembelajaran saat ini.

Sedangkan dimensi managing worik, family, and school dalam penelitian ini tidak 
berpengaruh dengan signifikan terhadap penyesuaian akademik. Hal ini menunjukkan dalam penelitian ini ketika mahasiswa dapat mempersiapkan ujian dalam minggu yang sama, mengatur waktu dengan efektif antara aktivitas kuliah dan pekerjaan, dan dapat berkumpul dengan keluarga tidak berpengaruh dengan signifikan terhadap penyesuaian akademik, seperti kemampuan mahasiswa menikmati tugas akademiknya, puas dengan prestasi akademiknya dan puas terhadap situasi pembelajaran saat ini.

\section{Kesimpulan}

Berdasarkan pembahasan dalam penelitian ini, peneliti menyimpulkan beberapa hasil penelitian sebagai berikut:

Sebagian besar mahasiswa yang sedang melaksanakan PJJ memiliki academic self efficacy yang rendah.

Sebagian besar mahasiswa yang sedang melaksanakan PJJ pun memiliki kemampuan penyesuaian akademik yang rendah

Academic Self Efficacy memberikan pengaruh yang signifikan terhadap Penyesuaian Akademik mahasiswa di kota Bandung yang sedang melaksanakan PJJ, yang artinya adalah mahasiswa yang memiliki tujuan kuliah yang jelas, memiliki motivasi untuk belajar dengan metode daring, puas terhadap prestasi yang didapat dan puas dengan situasi pembelajaran daring, hal tersebut terjadi ketika mahasiswa tersebut yakin bahwa dirinya mampu berinteraksi di dalam maupun di luar kelas ketika sedang melaksanakan pembelajaran jarak jauh, seperti yakin dapat berpartisipasi dalam diskusi kelas, yakin mencari waktu belajar diluar jadwal, yakin mampu mendapatkan nilai yang di inginkan, dan mampu mengatur waktu dengan efektif.

Dari keempat dimensi academic self efficacy, terdapat 3 (tiga) dimensi yang memberikan pengaruh signifikan terhadap penyesuaian akademik. Artinya semakin tinggi kemampuan mahasiswa dalam interaction at school, academic performance out class, dan academic performance in class, maka penyesuaian akademik mahasiswapun akan semakin tinggi.

Penelitian selanjutnya diharapkan dapat dapat meneliti dengan faktor lain yang mempengaruhi penyesuaian akademik, seperti pengalaman di kampus, coping style, dukungan sosial, hubungan dengan orang tua, dan core self evaluation \& traits selain self efficacy, seperti self esteem,dan locus of control. Selain itu, berdasarkan temuan penelitian ini, bagi mahasiswa dengan academic self efficacy yang rendah dipandang perlu meningkatkan academic self efficacy ketika sedang melaksanakan PJJ khususnya yang dapat meningkatkan penyesuaian akademik mahasiswa terhadap PJJ. Seperti memiliki enactive mastery experience atau pengalaman yang telah dilalui, vicarious experience atau pengalaman tidak langsung dengan memiliki model atau panutan untuk menjadi acuan dan menghilangkan keraguan sehingga menimbulkan keyakinan pada diri, social persuasion didapatkan ketika bercerita kepada orang lain agar mendapatkan support agar menimbulkan keyakinan pada diri, dan keadaan emosi/fisik yang stabil didapatkan dengan menjaga kesehatan baik fisik maupun psikis.

\section{Acknowledge}

Peneliti mengucapkan terima kasih kepada pihak perguruan tinggi di Bandung, dan seluruh subjek penelitian yang telah mengizinkan dan membantu proses pegambilan data sampai akhir penyelesaian penelitian ini.

\section{Daftar Pustaka}

[1] Alivernini, F., \& Lucidi, F. (2011). Relationship between social context, self-efficacy, motivation, academic achievement, and intention to drop out of high school: A longitudinal study. The Journal of Educational Research, 104(4), 241-252. https://doi.org/10.1080/00220671003728062

[2] Anderson J R., Guan, Y., Koe, Y. (2016). The Academic Adjustment Scale: Measuring The Adjustment Of Permanent Resident Or Sojourner Students. International Journal of 
Intercultural Relations, 54, 68-76. https://doi.org/10.1016/j.ijintrel.2016.07.006

[3] Argaheni, N. B. (2020). Sistematik Review : Dampak Perkuliahan Daring Saat Pandemi Covid-19 Terhadap Mahasiswa Indonesia. PLACENTUM: Jurnal Ilmiah Kesehatan Dan Aplikasinya, 8(2). DOI: https://doi.org/10.20961/placentum.v8i2.43008

[4] Arjanggi, R., Kusumaningsih, L P S. (2016). The Correlation between Social Anxiety and Academic Adjustment among Freshmen. Social and Behavioral Science, 219, 104-107. https://doi.org/10.1016/j.sbspro.2016.04.049

[5] Arlinka, F., Akmal S Z. (2017). Hubungan Antara School Engagement, Academic SelfEfficacy Dan Academic Burnout Pada Mahasiswa. Humanitas: Jurnal Psikologi. $1(2): 81$.

https://www.researchgate.net/deref/http\%3A\%2F\%2Fdx.doi.org\%2F10.28932\%2Fhum anitas.v1i2.418t

[6] Baker, R. W., \& Siryk, B. (1984). Measuring adjustment to college. Journal of Counseling Psychology, 31(2), 179-189. https://psycnet.apa.org/doi/10.1037/0022-0167.31.2.179

[7]Bandura, A. (1997). Self Efficacy: The Exercise of Control. New York: Freeman and Company. Retrieved by: https://connect.springerpub.com/content/sgrjcp/13/2/158

[8]Beyers, W \& Goossens, L. (2002). Concurrent and Predictive Validity of the Student Adaptation to College Questionnaire in a Sample of European Freshman Student. Educational and Psychological Measurement, 62, 527-538. https://doi.org/10.1177\%2F00164402062003009

[9]Bulplus. (21 April, 2020). Kuliah Online Beserta Keluhan dan Overthinking yang Menyertainya. Retrieved from: https://www.bulaksumurugm.com/2020/04/21/kuliahonline-beserta-keluhan-dan-overthinking-yang-menyertainya/. Diakses pada 18 Februari 2021

[10] Chemers, M., Hu, L., \& Garcia, B. (2001). Academic self-efficacy and first-year college student performance and adjustment. Journal of Educational Psychology, 93, 55-64. https://doi.org/10.1037/0022-0663.93.1.55

[11] CNNIndonesia.com. (2020, Juli 9). Survei Kemendikbud: 90 Persen Mahasiswa Mau Kuliah Tatap Muka. Diakses pada 29 Juli 2021 Dari: https://www.cnnindonesia.com/nasional/20200709143316-20-522787/surveikemendikbud-90-persen-mahasiswa-mau-kuliah-tatap-muka

[12] Crede, M. \& Niehorster, S. (2012). Adjustment to College as Measured by the Student Adaptation to College Questionnaire: a Quantitative Review of its Structure and Relationships With Correlates and Consequences. Educational Psychology Review, 24, 133-165.

[13] Didin, S F., Mardiono, I., Yanuarso, H D. (2020). Analisis Beban Kerja Mental Mahasiswa saat Perkuliahan Online Synchronous dan Asynchronous Menggunakan Metode Rating Scale Mental Effort. Jurnal Optimasi Sistem Industri. 13(1). https://doi.org/10.31315/opsi.v13i1.3501

[14] Feldt, R. C., Graham, M., \& Dew, D. (2011). Measuring Adjustment to College: Construct Validity of the Student Adaptation to College Questionnaire. Measurement and Evaluation in Counseling and Development, 44(2), 92-104. https://doi.org/10.1177/0748175611400291

[15] Friedlander, L. J., Reid, G. J., Shupak, N., \& Cribbie, R. (2007). Social support, self-esteem, and stress as predictors of adjustment to university among first-year undergraduates. Journal of College Student Development, 48(3), 259-274

[16] Griffiths, B. (2016). A Faculty's Approach to Distance Learning Standardization. Teaching and Learning in Nursing, 11(4), 157-162. https://doi.org/10.1016/j.teln.2016.04.004

[17] Hasanah, U., Ludiana., Immawati., H, Liviana, P. (2020). Gambaran Psikologis Mahasiswa Dalam Proses Pembelajaran Selama Pandemi Covid-19. Jurnal Keperawatan Jiwa, 8 (3), 299 - 206. 
[18] Indrawati, B. (2020). Tantangan dan Peluang Pendidikan Tinggi Dalam Masa dan Pasca Pandemi Covid-19. Jurnal Kajian Ilmiah, 1(1), $39 \quad$ - 48. https://doi.org/10.31599/jki.v1i1.261

[19] Javed, F. (2020). Adaptation Challenges Faced by Pakistani University Entrants. Student Success Journal, 11(2), p.41-51. https://doi.org/10.5204/ssj.v11i3.1164

[20] Muda Kompas. (2020). Keluhan Mahasiswa Baru Dalam Perkuliahan Secara Daring. Diakses pada 21 April, 2021dari https://muda.kompas.id/baca/2020/11/27/keluhanmahasiswa-baru-dalam-perkuliahan-secara-daring/

[21] Mudhovozi, P. (2012). Social and academic adjustment of first-year university students. Journal Social Science, 33(2), 251-259. https://doi.org/10.1080/09718923.2012.11893103

[22] Mutambara J. \& Bhebe V. (2012). An Analysis of the Factors Affecting Students Adjustment at a University in Zimbabwe. Journal of International Education Studies, 5, (6), 244-250. Retrieved From: https://eric.ed.gov/?id=EJ1067068

[23] Ningsih, S. (2020). Persepsi Mahasiswa Terhadap Pembelajaran Daring Pada Masa Pandemi Covid-19. JINOTEP: Jurnal Inovasi Teknologi Pembelajaran, 7 (2). DOI: 10.17977/um031v7i22020p124

[24] Open Data Kota Bandung. (2020 April 16). Data Spasial Sub Wilayah Kota Bandung. Diakses pada 13 Januari, 2021 dari http://data.bandung.go.id/

[25] Pajares, F. (1996). Self-Efficacy Beliefs In Academic Settings. Review of educational research, 66(4), 543-578. https://doi.org/10.3102/00346543066004543

PDDikti. (2020). Data Mahasiswa Perguruan Tinggi. Diakses pada 14 Januari 2021 dari https://pddikti.kemdikbud.go.id/

[26] Rahayu, M N M., Arianti, R (2020). Penyesuaian Mahasiswa Tahun Pertama Di Perguruan Tinggi: Studi Pada Mahasiswa Fakultas Psikologi UKSW. Jurnal Psikologi Sains dan Profesi, 4(2) : 73-84. https://doi.org/10.24198/jpsp.v4i2.26681

[27] Ririen, D., Hartika, D. (2021). Identifikasi Kesulitan Belajar Mahasiswa pada Mata Kuliah Statistika Selama Masa Pandemi Covid-I9. Jurnal Ilmiah Universitas Batanghari Jambi, 21(1): 148-155. DOI 10.33087/jiubj.v21i1.1236

[28] Sadikin, A., \& Hamidah, A. (2020). Pembelajaran daring di tengah wabah COVID-19. Jurnal Ilmiah Pendidikan Biologi, 6(2), 214-224. https://doi.org/10.22437/bio.v6i2.9759

[29] Sa'idah, S., \& Laksmiwati, H. (2017). Dukungan Sosial dan Self efficacy dengan Penyesuaian Diri Pada Siswa Tingkat Pertama di Pondok Pesantren. Jurnal Psikologi Teori Dan Terapan, 7(2), 116. https://doi.org/10.26740/jptt.v7n2.p116-122

[30] Saniskoro, B. S. R., \& Akmal, S. Z. (2020). The role of college adjustment on academic stress of migrant students in Jakarta. Jurnal Psikologi Ulayat: Indonesian Journal of Indigenous Psychology, 4(1), 96-106. https://doi.org/10.24854/jpu67

[31] Sharma, B. (2012). Adjustment and Emotional Maturity Among First Year College Students. Journal of Social and Clinical PsychologyVol. 9 No3, 32-37. Diakses dari: https://gcu.edu.pk/wp-content/uploads/2020/04/pjscp2012july-5.pdf

[32] Singh, G.; O'Donoghue, J.; and Worton, H. (2005). A Study Into The Effects Of eLearning On Higher Education, Journal of University Teaching \& Learning Practice, 2(1). Retrieved from: https://ro.uow.edu.au/jutlp/vol2/iss1/3

[33] Smith, H. M., \& Betz, N. E. (2002). An examination of efficacy and esteem pathways to depression in young adulthood. Journal of Counseling Psychology, 49(4), 438-448. https://doi.org/10.1037/0022-0167.49.4.438

[34] Sopiyanti, F. (2011). Pengaruh Self Efficacy Terhadap Penyesuaian Akademik Mahasiswa. Jurnal Ilmiah Psikologi, 4(1). https://doi.org/10.15575/psy.v4i1.2197

[35] Susanti, E. dan Sholeh, M. (2008). Rancang Bangun Aplikasi e-learning. Jurnal Teknologi, 1(1). Retrieved From: https://www.researchgate.net/profile/Erma_Susanti/publication/295906249_Rancang_B 
angun_Aplikasi_Elearning/links/56cfbfd608ae85c82344adf3/Rancang-BangunAplikasi-Elearning.pdf

[36] Taipjutorus, W., Hansen, S., \& Brown, M. (2012). Improving Learners' Self-Efficacy In A Learner-Controlled Online Learning Environment: A Correlational Study. Acilite 2012 Future Chellenges. Retrieved https://www.ascilite.org/conferences/Wellington12/2012/images/custom/taipjutorus,_wi dchaporn_-_improving.pdf

[37] Tuncay, N, Uzunboylu, H \& Teker, N. (2011). Students Evaluation of Edu 2.0: a Case Study. Procedia - Social and Behavioral Sciences, (28), 948 - 956. Retrieved From: https://www.sciencedirect.com/science/article/pii/S1877042811026140

[38] Warsito, H. (2012). Hubungan Antara Self-Efficacy Dengan Penyesuaian Akademik Dan Prestasi Akademik (Studi Pada Mahasiswa FIP Universitas Negeri Surabaya ). PEDAGOGI: Jurnal Ilmu Pendidikan, 9 (1). Retrieved From: http://ejournal.unp.ac.id/index.php/pedagogi/article/view/119/pdf

[39] Zajacova, A., Lynch, S. M., \& Espenshade, T. J. (2005). Self-efficacy, stress, and academic success in college. Research in Higher Education, 46(6), 677-706. http://dx.doi.org/10.1007/s11162-004-4139-z. 